
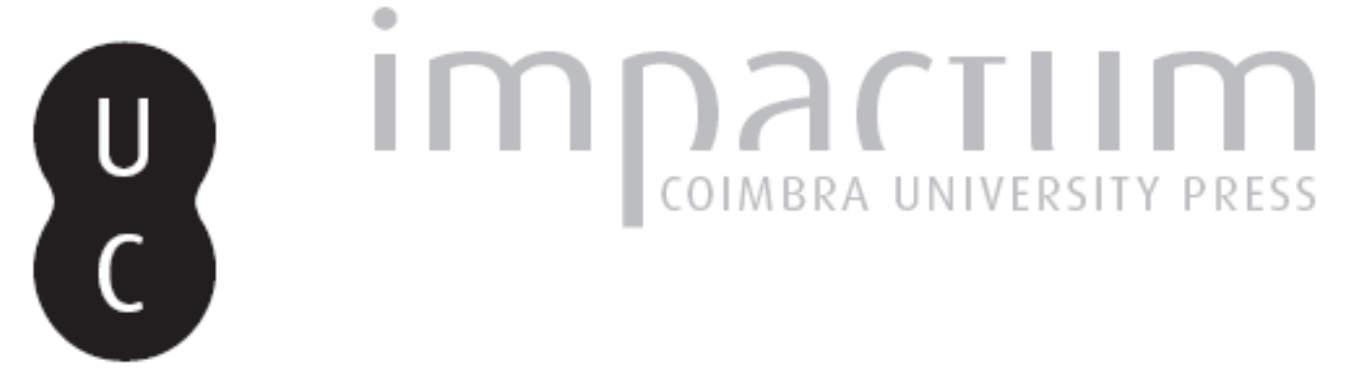

\title{
Impactes ambientais em áreas mineiras activas: o caso da Ribeira do Bodelhão, Minas da Panasqueira, Centro de Portugal
}

Autor(es): $\quad$ Gonçalves, Anselmo Casimiro Ramos

Publicado por: Associação Portuguesa de Riscos, Prevenção e Segurança

URL persistente:

URI:http://hdl.handle.net/10316.2/35859

DOI:

DOI:http://dx.doi.org/10.14195/1647-7723_19_5

Accessed : $\quad$ 26-Apr-2023 07:54:51

A navegação consulta e descarregamento dos títulos inseridos nas Bibliotecas Digitais UC Digitalis, UC Pombalina e UC Impactum, pressupõem a aceitação plena e sem reservas dos Termos e Condições de Uso destas Bibliotecas Digitais, disponíveis em https://digitalis.uc.pt/pt-pt/termos.

Conforme exposto nos referidos Termos e Condições de Uso, o descarregamento de títulos de acesso restrito requer uma licença válida de autorização devendo o utilizador aceder ao(s) documento(s) a partir de um endereço de IP da instituição detentora da supramencionada licença.

Ao utilizador é apenas permitido o descarregamento para uso pessoal, pelo que o emprego do(s) título(s) descarregado(s) para outro fim, designadamente comercial, carece de autorização do respetivo autor ou editor da obra.

Na medida em que todas as obras da UC Digitalis se encontram protegidas pelo Código do Direito de Autor e Direitos Conexos e demais legislação aplicável, toda a cópia, parcial ou total, deste documento, nos casos em que é legalmente admitida, deverá conter ou fazer-se acompanhar por este aviso.

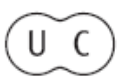




\section{territorium}

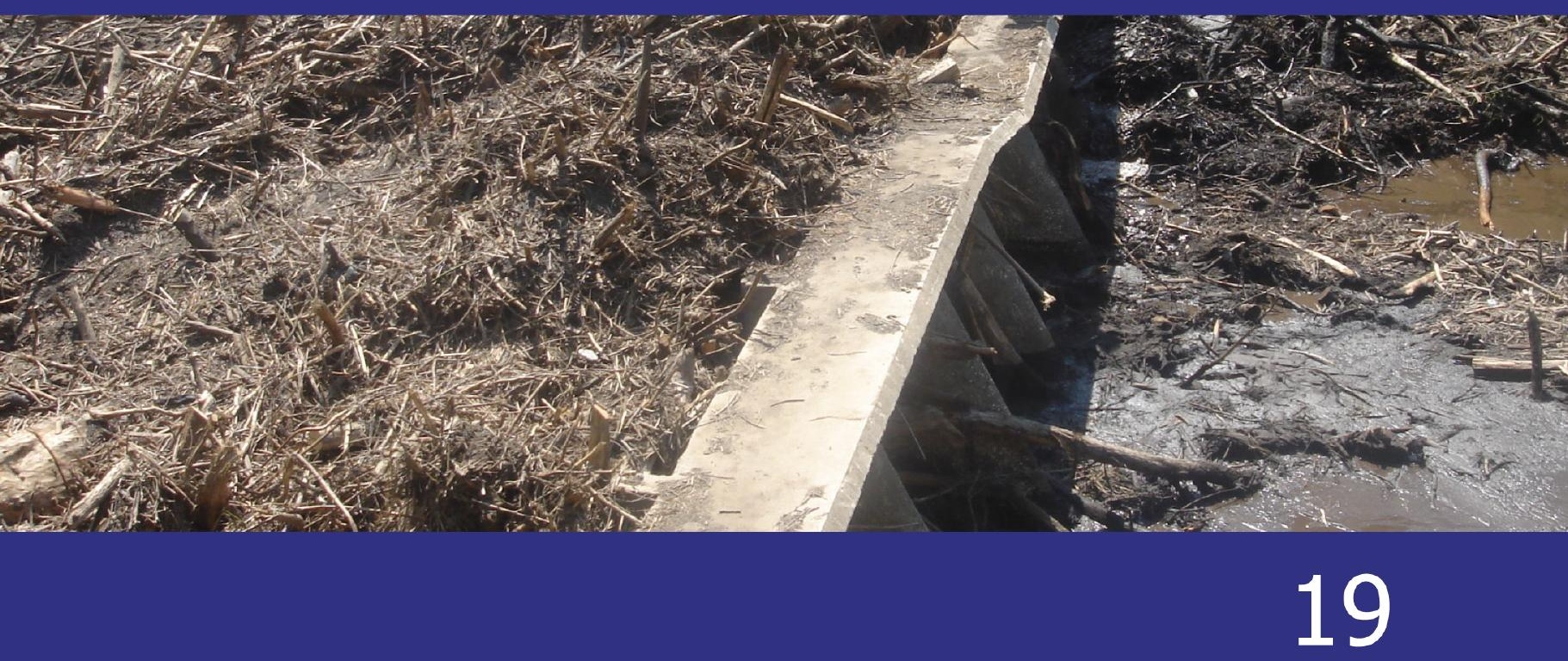

\section{Reequacionar o Conhecimento dos Riscos e das Catástrofes}

Revista da Associação Portuguesa de Riscos, Prevenção e Segurança 
territorium 19, 2012, 43-49

journal homepage: http://www.uc.pt/fluc/nicif/riscos/Territorium/numeros_publicados

IMPACTES AMBIENTAIS EM ÁREAS MINEIRAS ACTIVAS - O CASO DA RIBEIRA DO BODELHÃO, MINAS DA PANASQUEIRA, CENTRO DE PORTUGAL*

\author{
Anselmo Casimiro Ramos Gonçalves \\ Investigador do CEGOT \\ Universidade de Coimbra \\ Anselgoncalves@gmail.com
}

RESUMO

Através deste trabalho pretende-se dar a conhecer o estado de contaminação das águas na envolvente das Minas da Panasqueira, no troço entre a Barroca Grande e a foz da Ribeira do Bodelhão, bem como os potenciais efeitos da dispersão dos contaminantes para áreas limítrofes, no caso o rio Zêzere, e as consequências associadas.

Palavras chave: Escombreiras, escorrência, contaminantes, metais pesados.

\title{
RESUMEN
}

Impactos ambientales en áreas de mineria activo: el caso de Ribeira de Bodelhão, Minas de Panasqueira - A través de este trabajo se pretende presentar el estado de la contaminación de las aguas por participación de las minas de Panasqueira, en la sección entre la Barroca Grande y la foz de Ribeira do Bodelhão, así como los posibles efectos de la dispersión de contaminantes a zonas vecinas, en este caso, el río Zêzere, y las consecuencias asociadas.

Palabras clave: Montones, escorrentía superficial, contaminantes, metales pesados.

\section{RÉSUMÉ}

Les impacts environnementaux sur les zones d'exploitation active - le cas de Ribeira Bodelhão, Mines de Panasqueira Dans ce travail, on veut présenter l'état de la pollution des eaux qui entourent les mines de Panasqueira, dans la section entre la Barroca Grande et l'embouchure de la Ribeira do Bodelhão, ainsi que les effets potentiels de la dispersion des contaminants dans les régions voisines, dans ce cas, le fleuve Zêzere, et les conséquences associées.

Mots-clé: Éboulis, ruissellement, polluents, métaux lourds.

\section{ABSTRACT}

Environmental impacts on active mining areas - the case of Ribeira do Bodelhão Panasqueira Mines - Through this work is intended to present the state of pollution of the waters in the area of Panasqueira mines, in the section between the Barroca Grande and the mouth of Ribeira do Bodelhão, as well as the potential effects of dispersal of pollutants into the neighbouring areas, in this case the River Zêzere, and the associated consequences..

Key words: Heaps, runoff, contaminatives, heavy metals.

* O texto deste artigo corresponde à comunicação apresentada ao II Congresso Internacional de Riscos e VI Encontro Nacional, tendo sido submetido para revisão em 03-05-2010, tendo sido aceite para publicação em 21-02-2011.

Este artigo é parte integrante da Revista Territorium, n. ${ }^{\circ} 19,2012,{ }^{\circ}$ RIscos, ISBN: 0872- 8941. 


\section{Enquadramento Geral}

A extracção mineral é uma de entre outras actividades humanas que têm contribuído nos últimos cem anos para a degradação ambiental, quer do local onde se encontram instaladas, quer por vezes, da região envolvente (QUADRo I).

$\mathrm{Na}$ verdade a procura do minério e da sua eventual utilização remonta aos primórdios da existência humana, tendo desempenhado desde essa altura um papel essencial na sua sobrevivência, e no seu progresso.

Desde a pedra lascada aos dias de hoje o Homem não fez mais do que utilizar a inteligência em benefício de si próprio para beneficiar da riqueza da terra e melhorar a sua qualidade de vida.

Num país como o nosso, com uma fortíssima tradição mineira, basta atentarmos nas inúmeras explorações de cobre, estanho, volfrâmio, ferro, urânio, ouro e prata, e na forma como estas explorações foram conduzidas (QUADRO I), para compreendermos a existência de um passivo ambiental deveras negativo, e uma imagem que nem sempre espelhava aquilo que se passava no local. Segundo Barroqueiro (2005) a verdade é que na maior parte das vezes não existia controlo dos efluentes líquidos perigosos, nomeadamente das lamas ácidas resultantes dos processos de separação e posterior lavagem do minério. Ainda assim, existia uma ténue prática de controlo das escombreiras.

É do conhecimento geral que a actividade mineira até há relativamente pouco tempo, norteou-se quase exclusivamente para um aproveitamento económico das jazidas, sem mais qualquer tipo de preocupação de cariz ambiental, o que causou e, causa hoje sérios problemas ambientais associados ao encerramento de minas que posteriormente criaram um agravamento do passivo ambiental.
Não obstante os problemas de índole ambiental, contribuíram decisivamente para o desenvolvimento económico e social de regiões particularmente desfavorecidas, situadas muitas vezes no interior profundo do País, onde as alternativas de emprego são escassas ou nulas (D. Carvalho, 2005).

Em Portugal na actualidade estão activas apenas três explorações mineiras (Neves Corvo, Aljustrel e Panasqueira), não significando por isso, que o sector tenha perdido relevância. De facto, as Minas da Panasqueira situadas na vertente sul da cordilheira montanhosa da Serra da Estrela, numa zona esquecida da Beira Interior são as maiores produtoras de concentrados de tungsténio (W) da Europa. Nas Minas da Panasqueira são ainda explorados, mas em menor proporção, cobre (Cu) e estanho (Sn).

\section{Enquadramento Geográfico das Minas da Panasqueira}

O Couto Mineiro da Panasqueira localiza-se no distrito de Castelo Branco, mais propriamente nos limites dos concelhos da Covilhã, Fundão e Pampilhosa da Serra (fig. 1), com uma área total de $21 \mathrm{Km}^{2}$, que associa 42 concessões mineiras, a Panasqueira e o Cabeço do Pião as primeiras, a que se juntaram, posteriormente, as explorações do Vale da Ermida, Vale das Freiras e Barroca Grande. Fica situado em pleno Maciço Hespérico, na vertente sul da serra da Estrela, precisamente mais precisamente no maciço da serra do Açor, a poente da depressão tectónica bem conhecida pela designação de "Cova da Beira".

A sul destas minas passa, no sentido Nascente - Poente, o rio Zêzere, principal receptor de todas as linhas de água da região e de onde se retirava toda a água fundamental ao tratamento mecânico do minério extraído.

QUADRo I - Fases do empreendimento mineiro e principais impactes negativos no ambiente.

\begin{tabular}{|c|c|c|}
\hline Fases & Actividades & Impactes Potenciais no Ambiente \\
\hline Prospecção, pesquisa & $\begin{array}{l}\text { - Prospecção; } \\
\text { - Reconhecimento geoquímico, geofísico; } \\
\text { - Execução de sondagens, trincheiras }\end{array}$ & - Geralmente baixos ou sem impacte \\
\hline $\begin{array}{l}\text { Extracção: Desmonte } \\
\text { Tratamento do minério }\end{array}$ & $\begin{array}{l}\text { - Estudos de viabilidade de engenharia; } \\
\text { - Consulta pública; } \\
\text { - Construção a mina e pré produção; } \\
\text { - Extracção, britagem e moagem do minério; } \\
\text { - Separação / concentração física e química } \\
\text { das espécies minerais. }\end{array}$ & $\begin{array}{l}\text { - Descarga deáguas ácidase contaminantes } \\
\text { (metaais pesados, compostos orgânicos } \\
\text { originados nas reacções químicas } \\
\text { usadas no processo de separação dos } \\
\text { metais, cianetos (ouro), e amóńia); } \\
\text { - Resíduos da extracção (escombreiras); } \\
\text { - Erosão, assoreamento de lagos e linhas } \\
\text { de água; } \\
\text { - Poeiras e ruído }\end{array}$ \\
\hline $\begin{array}{l}\text { Gestão dos Resíduos } \\
\text { pós-operação }\end{array}$ & - Abandono e recuperação da mina & $\begin{array}{l}\text { - Descarga de contaminantes em águas } \\
\text { (metais pesados quando exista uma } \\
\text { escorrência natural de meios ácidos) }\end{array}$ \\
\hline
\end{tabular}


O centro mineiro criado pela Beralt Tin \& Wolfram situa-se na povoação da Barroca Grande, onde hoje se concentra toda a actividade mineira. Dista cerca de $30 \mathrm{Km}$ da vila do Fundão e $40 \mathrm{Km}$ da vila de Pampilhosa da Serra.

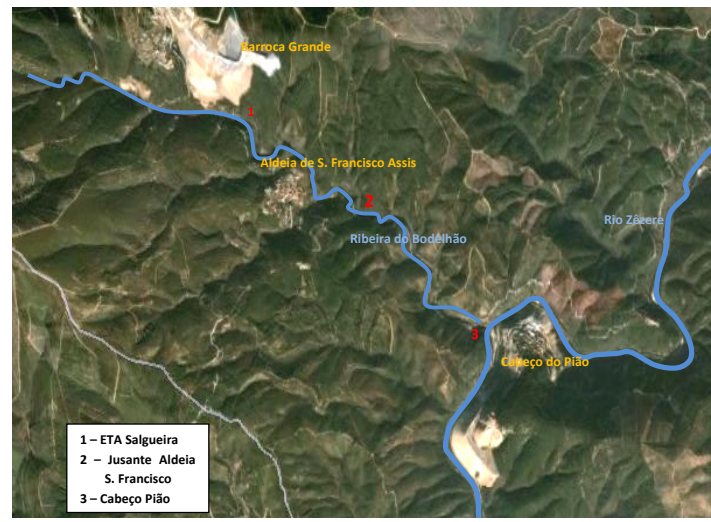

Fig. 1 - Enquadramento e localização dos pontos de recolha de amostras de água. Fonte: Google Earth.

\section{Enquadramento Geológico}

As Minas da Panasqueira localizam-se na Zona Centro Ibérica do Maciço Hespérico (ocidente da Cova da Beira) e integram uma das províncias metalogénicas estanovolfrâmiticas mais importantes da Europa. Esta província forma o denominado Arco do Estanho (BARRoQUEIRo, 2005).

0 couto mineiro encontra-se em terrenos constituídos por xistos (xistos verdes), durante as fases iniciais compressivas da Orogenia Hercínica. As rochas pertencem ao Pré-câmbrico superior e ou Câmbrico inferior (C. DE SÁ et al., 1999). No entanto nesta área existem, numerosas manifestações eruptivas (básicas e ácidas) (D. THADEU, 1951). A presença de granitos no subsolo é resultado da proximidade com o Complexo Granítico Hercínico do Norte de Portugal, constituindo a Serra da Estrela a principal massa granítica, relacionada com a instalação dos filões mineralizados na área mineira da Panasqueira (C. DE SÁ et al., 1999). A região é atravessada por uma série de falhas quase verticais no sentido Norte e Nordeste. Pensa-se que estas falhas foram iniciadas com movimentos do tipo "strike-slip" durante o episódio Hercínico e reactivadas durante a orogenia Alpina.

A disposição sub-horizontal dos filões mineralizados (foto 1), permitiu o desenvolvimento de um tipo particular de lavra mineira, usualmente designada por pillar and room (Cavey \& Gunning, 2006).

\section{Solos}

Relativamente aos solos desta área analisada e segundo a Carta de Solos de Portugal na escala 1:50.000 - 20 D (1980) e a Carta de Capacidade de Uso do Solo de Portugal na escala 1:50.000 - 20 D (1980), os solos que principalmente ocorrem a norte da Aldeia da Barroca

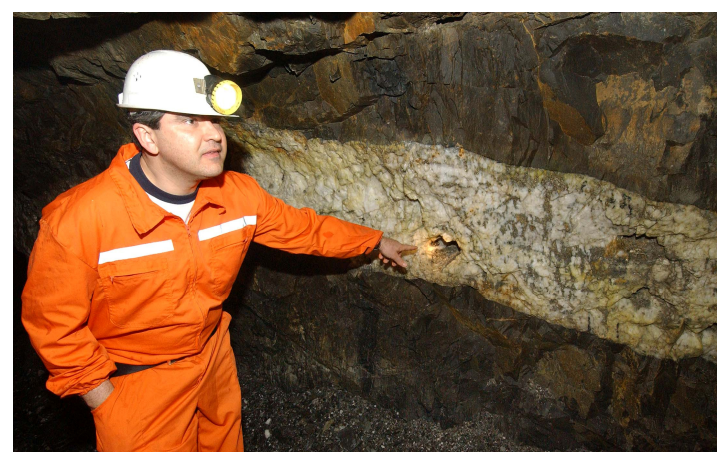

Foto 1 - Filão mineralizado sub-horizontal na mina da Panasqueira (fotos do autor).

Grande (actual boca da mina também conhecido por Rebordões) são Solos Litólicos Húmicos de Xistos e Grauvaques (Px) e Solos Mediterrâneos Pardos de Xistos e Grauvaques (Mnx) a sul predominam Solos Paralitossolos ou Rankers de Xistos ou Grauvaques (QX) e Litossolos de Xistos e Grauvaques (EX). Os declives da área são bastante acentuados variando entre os 10 e os $40 \%$, havendo por isso o predomínio de solos delgados. Desta forma, e pela sua natureza cascalhenta, estes são bastantes desfavoráveis ao desenvolvimento da agricultura, que se limita aos terrenos de aluvião no fundo dos vales, percorridos por pequenas ribeiras (C. DE SÁ et al., 1999).

A acidez dos solos é devida às características dos materiais que thes dão origem. Ou seja, os solos desenvolvidos sobre escombreiras ou solos sob influência de águas de lixiviação de escombreiras são por norma mais ácidos que os solos desenvolvidos sobre xistos, porque os primeiros têm a influência dos minerais contidos nas mineralizações, nomeadamente os sulfuretos que acidificam o meio após alteração por oxidação e hidrólise.

A erosão e o escoamento superficial desorganizado, aliados à natureza dos solos são preocupações crescentes na área, diminuindo ainda mais a possibilidade de desenvolver qualquer tipo de agricultura, daí que desde o início, a exploração mineira tenha tido grande importância como meio de subsistência das populações.

\section{Hidrologia}

A ribeira do Bodelhão situa-se no concelho da Covilhã e está incluída na bacia do Rio Zêzere e consequentemente na do Rio Tejo (fig. 1).

No couto mineiro ocorrem cerca de seis pequenas linhas de água que confluem para a Ribeira do Bodelhão, afluente do Rio Zêzere (C. DE SÁ et al., 1999). Apesar da densa rede de drenagem, as linhas de água caracterizamse por apresentar um regime temporário apresentando a maioria delas um caudal nulo durante os meses de Verão. 
Devido à natureza da rocha de substrato, o xisto, a rede hidrográfica é complexa sendo o traçado das ribeiras muito sinuosos.

A ribeira do Bodelhão contorna as actuais escombreiras, num vale paralelo às mesmas (foto 2 ). Para esta são drenadas as águas de escorrência das escombreiras e as águas tratadas na Estação de Tratamento de Águas da Salgueira (ETA) (onde se incluem as águas vindas do interior da mina).

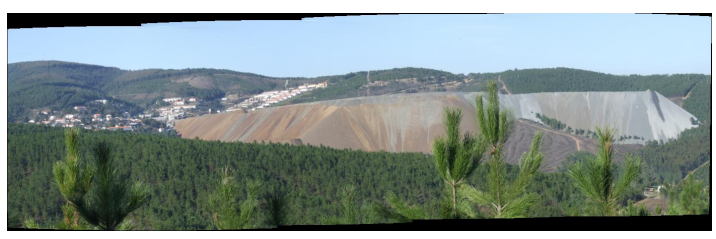

Foto 2 - Escombreiras activas na Barroca Grande. Foto do autor em Janeiro de 2010.

Além das ribeiras, no interior da mina ocorrem inúmeras fontes de água subterrânea que alimentam as operações mineiras.

Alerações ambientais causadas pela actividade extractiva no couto mineiro da Panasqueira

As Minas da Panasqueira não são, no panorama nacional, uma excepção, em especial no que diz respeito ao troço entre a Barroca Grande e o Cabeço Pião (concelho do Fundão).

Actualmente e por esta mina se manter em actividade desenvolve-se aquela que será porventura a maior escombreira deste couto mineiro e mesmo do todo nacional, paredes meias com a ribeira do Bodelhão e com o rio Zêzere (foto 2, fig. 2).

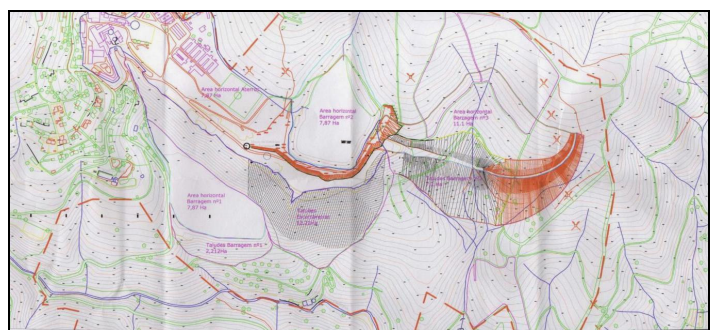

Fig. 2 - Escombreira activa da Barroca Grande. Carta topográfica do plano de expansão da escombreira, elaborado já em 02.2010. Gentilmente cedida pela S.B.T.W.P.

A enorme escombreira aqui referida, é composta essencialmente por partículas de quartzo, xistos e grauvaques que, de alguma forma, estão associados ao jazigo e apresentam granulometria homogénea. Assim temos: 1) rochas de cobertura, encaixantes ou da ganga que normalmente apresentam uma granulometria regular, embora tendencialmente grosseira e com uma distribuição espacial distinta, como consequência da segregação que as partículas sofrem ao serem depositadas em escombreiras e por não estarem alterados (ITGE, 1989; CostA, 1992); 2) detritos resultantes do tratamento, normalmente com uma granulometria inferior à dos materiais anteriores (ITGE, 1989).

Após o abandono da exploração, as escombreiras passam a sofrer constantes descargas de materiais, RSU e RSI e como se encontram desprovidas de vegetação, são visíveis a grande distância, essa percepção é-nos dada pelas formas angulares da escombreira e contribui decisivamente para agravar o foco de poluição mesmo no curso do rio.

Frequentemente são as escombreiras de minas abandonadas o principal foco de poluição, por incluírem sulfuretos capazes de reagirem até formarem águas ácidas, aumentando o poder de dissolução de elementos químicos tóxicos, lixiviando-os e transportando-os, por vezes até distâncias consideráveis da origem, e resultando na contaminação de águas superficiais ou subterrâneas.

M. Machado (1994, p. 4) refere que no caso da contaminação do rio Zêzere por cobre e arsénio "esta é significativa nas fases líquidas e em suspensão referentes à ribeira do Bodelhão, (...), no caso do ferro não pode ser imputado exclusivamente à mina mas devido também a este metal ser introduzido no meio aquoso mediante processos de lexiviação das margens das ribeiras (no caso a partir das escombreiras), ou do próprio leito do rio", que em época de estiagem pode ver-se uma carapaça ferruginosa que atapeta o fundo, este processo, segundo P. VAlCARlos (1993), obedece a uma série de mecanismos complexos e catalisados pela presença de bactérias que, produzem a oxidação de sulfuretos, libertando ácido sulfúrico e metais e ou semi-metais em solução.

Sobre a acção dos produtos químicos resultantes da exploração mineira, C. CostA (1992, p. 63), afirma que, "A actividade mineira que se destina à obtenção de substâncias úteis ao Homem mas de incontestável perigosidade (arsénio, chumbo, mercúrio...) pode pôr em causa a saúde pública e o ambiente, em particular quando os resíduos da extracção acumulados em escombreiras não são convenientemente tratados e, após o seu abandono, são sujeitos à erosão e transporte originando os chamados lixiviados (ou águas lixiviantes) que podem afectar de forma grave os recursos hídricos (superficiais e subterrâneos) de toda a região".

A ausência de responsabilidade que progressivamente se instalou com o encerramento de minas, cria nos dias de hoje sérias dificuldades à aplicação do princípio do poluidor - pagador, pelo que perante tal estado de coisas compete hoje ao Estado a resolução desses problemas. Ao contrário, tem havido por parte da BTWP nos últimos anos alguma preocupação com a monitorização das águas vindas da mina (fonte do Masso e da Salgueira). E. CRESPo (2006, p. 1) manifesta mesmo preocupação com a dificuldade actual da ETAR 
existente já não ter capacidade para tratar de forma integral os efluentes líquidos vindos quer da mina, quer ainda da barragem de lamas. Nessa nota apresenta soluções para o problema e propõe mesmo a construção de uma outra ETAR, com capacidade três vezes superior à actual, ou seja com capacidade para tratar cerca de 900 a 1000 m3 de efluentes/hora. Retemos, no entanto, que desde 2006 até Abril de 2010, a empresa ainda não concretizou tal projecto.

No nosso entendimento, a área entre a Barroca Grande e o Cabeço do Pião, sofre claramente os efeitos negativos gerados pela actividade da indústria mineira, ao tempo sem qualquer tipo de preocupação ambiental, afectando deste modo o meio físico e o meio social. O desenvolvimento deste tipo de indústria cria nos locais onde está instalada, uma série de alterações, designadas por impactes ambientais, os quais podem vir a revestir-se de um carácter positivo ou negativo. Esta avaliação é feita tendo em conta o conhecimento das características biogeofísicas, económicas e sociais do meio receptor, a capacidade de auto depuração do meio, a viabilidade de recuperação posterior, a dimensão temporal do impacto e a sensibilidade do governo na definição da política ambiental.

As explorações mineiras pela sua própria natureza, desequilibram o ambiente na sua área de intervenção e envolvente. Na área em estudo já não nos preocupa a fase de implantação nem de desenvolvimento da actividade, visto que esta há mais de 40 anos na Panasqueira e à 15 anos no Cabeço Pião deixou de existir. No entanto, este tipo de explorações cria sempre diversos tipos de acções negativas. Preocupa-nos essencialmente o nível de abandono a que estão votadas estas instalações e respectivas escombreiras, assim como a falta de acompanhamento da escombreira e da barragem de lamas existente no Cabeço do Pião (foto 3 e 4).

Geralmente as escombreiras evoluem em área e altura na proporção directa do aprofundamento da exploração, como é o caso das da Barroca Grande e do Cabeço do Pião. Segundo o ITGE (1989), a escombreira que podemos observar hoje na Barroca Grande (foto 2) quer ainda a do Cabeço do Pião (foto 4), resultam de uma acumulação de materiais efectuado entre 1895 e 2009, seguindo o princípio do despejo livre. Nesse prisma é possível observar a escombreira com várias dezenas de metros de altura a uma distância considerável no caso vários km.

Os materiais que compõem a escombreira são heterogéneos, resultante dos diversos tipos de exploração e tratamento que estes encerram. Independentemente dos problemas geotécnicos que lhe estão associados (instabilidade de taludes, erosão laminar, ravinamentos, erosão eólica, assentamentos, modificações na drenagem, etc...), e que, por vezes, podem ser os mais importantes, são os impactes de natureza paisagística que chamam mais a atenção por parte das populações e, principalmente, dos visitantes dessas regiões, em particular em meios rurais de acentuada beleza cénica.

\section{Principais Fontes de Contaminação Ambiental}

As principais fontes de contaminação ambiental existentes na actualidade, estão concentradas entre a Barroca Grande, e o Cabeço do Pião, entre estas duas localidades surgem as escombreiras já referenciadas. Estas apresentam um maior ou menor estado de vegetação natural que tem a ver directamente com a idade das mesmas.

A escombreira da Barroca Grande é das mais preocupantes, por também incluir a actual boca da mina, a Lavaria e a Estação de Tratamento de Água (ETA) da Salgueira (construída em 1957) e que despeja directamente para a ribeira do Bodelhão.

A escombreira recente da Barroca Grande, prolonga-se ao longo de cerca de $1,5 \mathrm{~km}$, ao longo desta ribeira, apresentando declives bastante acentuados e a inexistência de qualquer tipo de vegetação que trave a velocidade de escorrência da água, torna-a um potencial fonte de contaminação por águas de percolação e por escorrência. Além disso os desmoronamentos poderão também ocorrer, pois a escombreira é constituída principalmente por partículas de quartzo, xistos,

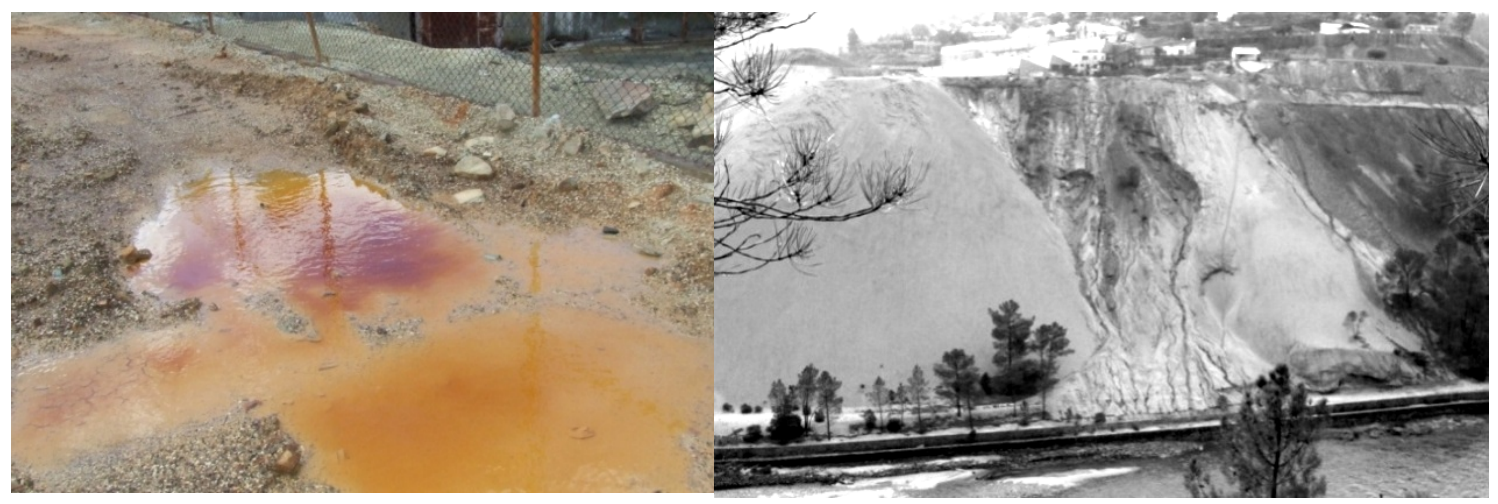

Foto 3 e 4 - As escorrências ácidas são visíveis nas antigas instalações no Cabeço do Pião da BTWP escorrência visível nas escombreiras que contactam com o rio Zêzere. 
grauvaques e algum granito devido à já intersecção por trabalhos mineiros da cúpula de greisen. Este material é frequentemente usado na construção de estradas. As partículas mais finas são as mais preocupantes, por serem resultado do circuito do cobre contendo mais de $25 \%$ de Arsénio (As) (CAvey \& Gunning, 2006).

Situadas na escombreira da Barroca Grande, existem três Barragens de Lamas (QUADRo II), onde as lamas da ETA são colocadas para secagem e percolação em profundidade, com a agravante destas lagoas serem apenas semi impermeabilizadas, o que constitui elevado perigo de contaminação das águas subterrâneas, das águas de escoamento superficial (incluindo a Ribeira do Bodelhão) e também dos solos adjacentes.

Na ETA é tratada a água vinda do interior da mina, durante os meses de Inverno podem ocorrer valores superiores a $1000 \mathrm{~m} 3 / \mathrm{h}$ e nos meses de Verão $250 / 300 \mathrm{~m} 3 / \mathrm{h}$ ). No entanto, como a ETAapenas tem capacidade de tratar $300 \mathrm{~m} 3 / \mathrm{h}$, grande parte do caudal debitado no Inverno é desviado directamente para a ribeira sem ocorrer qualquer tratamento.

QuAdRo II - Dimensão das Barragens de lamas situadas na escombreira da Barroca Grande. Dados S.B.T.W.P - 2010.

\begin{tabular}{|c|c|c|}
\hline Barragens & $\begin{array}{c}\text { Área Horizontal } \\
\text { (hectares) }\end{array}$ & $\begin{array}{c}\text { Área do Talude de } \\
\text { Suporte } \\
\text { (hectares) }\end{array}$ \\
\hline $\begin{array}{l}\text { Barragem 1 } \\
\text { desactivada }\end{array}$ & 7,87 & 2,21 \\
\hline Barragem 2 & 7,87 & 12,22 \\
\hline Barragem 3 & 11,1 & 7,20 \\
\hline
\end{tabular}

Além da água vinda do interior da mina (maior caudal de entrada), a ETA recebe água que se acumula na superfície da Barragem 1 (Velha) e águas vindas das Barragens Novas 2 e 3 e águas de infiltração da base da escombreira (captada por uma conduta de superfície). 0 tratamento das águas ocorre principalmente pela neutralização das mesmas, pela adição de cal (E. CRESPO, 2006).

Resumidamente, os focos de contaminação são:

-As escombreiras, principalmente a mais recente, pela existência de materiais sujeitos a deslizamentos, arrastamento de material particulado e lixiviado pelas águas de precipitação provocando a contaminação de solos, águas subterrâneas e superficiais.

-As barragens (semi-impermeabilizadas) para as quais são levadas as lamas de tratamento da ETA, sujeitas à eventual percolação em profundidade.

-As águas vindas do interior da mina, das barragens, etc., que estando a ser sujeitas a tratamento deficiente, podem ser fonte de dispersão/ mobilização de contaminantes para as águas superficiais e contaminação de solos adjacentes.

\section{Caracterização dos Riscos Ambiental e Toxicológico de Alguns Elementos}

Os elementos vestigiais podem causar efeitos adversos nas plantas, nos organismos do solo e aquáticos e noutros animais, incluindo o Homem. O Manganésio (Mn), Zinco (Zn) e Arsénio (As) são os elementos existentes mais frequentemente associados a intoxicações no Homem (VARENNES, 2006).

O envenenamento agudo causado por estes elementos é raro e está associado a acidentes durante a sua extracção ou processamento, não sendo usualmente consequência de níveis elevados nos solos.

No QUADRO III, podemos verificar que a jusante da escombreira as análises à água em circulação na ribeira do Bodelhão apresentam anomalias relativamente ao

QuADRo III - Análises de efectuadas semanalmente durante o mês de Dezembro de 2009.

\begin{tabular}{|l|c|c|c|c|c|c|}
\hline \multicolumn{1}{|c|}{ LOCAL } & {$[\mathrm{Cu}] \mathrm{ppm}$} & {$[\mathrm{Zn}] \mathrm{ppm}$} & {$[\mathrm{Fe}] \mathrm{ppm}$} & $\mathrm{Mn}] \mathrm{ppm}$ & {$[\mathrm{As}] \mathrm{ppm}$} & $\mathrm{pH} \mathrm{Média}$ \\
\hline A - MONT.SALG. & 0,25 & 2,00 & 0,55 & 1,64 & 0,0512 & 5,09 \\
\hline B - JUSA.SALG. & 1,08 & 8,20 & 1,96 & 7,40 & 0,143 & 5,25 \\
\hline C - RIB.BODEL. & 0,69 & 6,20 & 0,65 & 4,68 & 0,032 & 5,66 \\
\hline D - ZÊZE.MONT. & 0 & 0 & 0,21 & 0,01 & 0,0006 & 6,97 \\
\hline G - ZÊZE. PONTE & 0 & 0,16 & 0,25 & 0,04 & 0,00009 & 6,83 \\
\hline E - ZÊZE. JUS. & 0 & 0,05 & 0,30 & 0,06 & 0,0017 & 6,75 \\
\hline O/F CICLATOR SALGUEIRA & 0,09 & 1,18 & 0,49 & 4,74 & 0,013 & 8,70 \\
\hline O/F THICKENER SALGUEIRA & 0,06 & 0,72 & 0,34 & 4,11 & 0,008 & 9,03 \\
\hline O/F THICK.71" & 0,33 & 0,43 & 0,56, & 1,9 & 0,0065 & 9,21 \\
\hline RESTEVA NORTE & 37,6 & 35,8 & 114,00 & 58,6 & 0,611 & 2,72 \\
\hline RESTEVA SUL & 36,8 & 34,8 & 288,0 & 103,0 & 0,032 & 2,73 \\
\hline BOCA DA MINA & 2,12 & 15,0 & 12,2 & 15,8 & 0,282 & 4,58 \\
\hline ENTRADA DE ÁGUAS THICK.71" & 32,0 & 30,4 & 100,4 & 44,4 & 0,701 & 2,80 \\
\hline Valores Máximos Recomendados (O.M.S) & 0,20 & 2,00 & 5,00 & 0,20 & 0,01 & \\
\hline
\end{tabular}


Cobre, Zinco, Manganésio e Arsénio. Estas anomalias são em larga medida induzidas pela actividade mineira. Nestas mesmas análises de água influenciada pela exploração mineira surgem valores de $\mathrm{pH}$ extremamente ácidos e, portanto, francamente preocupantes.

Assim, e embora não existam dados técnicos e científicos, que nos permitam afirmar que existe perigo de contaminação química ao longo da ribeira do Bodelhão, não será, no entanto, de excluir liminarmente essa situação, até porque existe o risco real da influência de alguns metais pesados sobre os ecossistemas vizinhos da mina da Panasqueira e sobre o próprio Homem. Nessa perspectiva o actual cenário configura algum risco ambiental potencial à luz dos conhecimentos actuais.

\section{Conclusão}

Em jeito de conclusão, e como primeira medida, é necessário consciencializar as populações, principalmente as que estão mais próximas dos locais em questão, não só sobre os problemas a que estão expostas como também sobre a necessidade de desenvolver atitudes que contribuam para a preservação e conservação das zonas mineiras e consequentemente da biodiversidade que lhes está associada.

Assim, é importante preservar e valorizar os locais que ao longo do tempo sofreram substanciais alterações, principalmente pela acção humana, como é o caso do troço da ribeira do Bodelhão.

As medidas que deverão ser implementadas por ordem de prioridade são:

- Implementar rapidamente a construção de uma nova ETA com capacidade para tratar todas as águas da mina (como já referido neste texto);

- Valorizar e recuperar os habitats e as linhas de água presentes na zona, utilizando técnicas de remediação, controlando a erosão que se faz sentir principalmente nas zonas de maior declive e, controlando e fazer o devido tratamento da drenagem ácida visto que esta impede o desenvolvimento de cobertura vegetal, além de contribuir com maior ou menor intensidade para a poluição das águas correntes, tendo em vista minimizar os impactes ambientais (químico, físico e paisagístico) provocados pela exploração mineira;

- Implementar medidas tendentes à limpeza dos solos e dos aluviões nos terrenos marginais à ribeira do Bodelhão, onde ainda hoje se teima em praticar alguma agricultura e mesmo o apascentamento de gado;

- Manter uma vigilância apertada no que se refere à qualidade da água e dos solos;
- Iniciar acções de reflorestação, promovendo, sempre que possível a regeneração natural, para que se conserve os habitats e as espécies características da zona;

- Controlar as descargas de lixo na área por parte da população através da recolha e tratamento do mesmo, e;

- Ordenar e condicionar o acesso bem como as actividades turísticas ao longo do percurso mineiro desenvolvendo projectos de Parques Temáticos Mineiros.

\section{Bibliografia}

Andrade, A. A. Soares (2005) - "Lições de Geologia de Portugal". Departamento de Ciências da Terra da F.C.T.U.C (inédito).

Barroqueiro, Mário Luís Gaspar (2005) - "O Declínio de Centros Mineiros Tradicionais no Contexto de uma Geografia Industrial em Mudança. As Minas de Aljustrel e da Panasqueira". Dissertação de Mestrado em Geografia Humana e Planeamento Regional e Local apresentada à Faculdade de Letras da Universidade de Lisboa.

Carvalho, D. (2005) - Entrevista. Empresa de Desenvolvimento Mineiro. Disponível em: http://www.edm.pt/html/noticia20051109. htm.

Cavey, G. \& Gunning, D. (2006). Panasqueira Mine - Distrito de Castelo Branco, Portugal. Updated Technical Report. Primary Metals Inc. Orequest, Castelo Branco. $85 \mathrm{pp}$.

CostA, Carlos (1992) - “Aproveitamento e valorização de escombreiras e outros resíduos". Revista A Pedra, Ano XIV, n. ${ }^{\circ} 55$ / 56, Lisboa.

CRESPO, Eduardo Vilhena (2006) - "Renovação da ETAR da Salgueira". Nota Técnica interna, B.T.W.P.

Instituto Tecnológico Geominero de España (1989) - "Manual de restauración de terrenos y evaluación de impactos ambientales en minería". Serie: Ingenería GeoAmbiental, Ministerio de Industria y Energía.

Machado, Maria José do Canto (1994) - “Impacto Ambiental Das Minas da Panasqueira na Bacia Hidrográfica do Rio Zêzere". Contribuição para um estudo. Relatório Interno do I.G.M, Lisboa.

Pagés Valcarlos, J. L. (1993) - “Las alteraciones ambientales en sistemas naturales provocadas por la minería metálica". Cuaderno Lab. Xeolóxico de Laxe, Vol. 18, pp. 289 - 306.

SÁ, Correia; Nalque, R.A; Nobre, Edmundo (1999) - "Minas da Panasqueira: 100 Anos de História Mineira", Boletim de Minas, 36, (1), Jan. / Mar., pp. 3 - 22.

VARennes, A. (2006). Apontamentos da Disciplina Monitorização de Ecossistemas. Instituto Superior de Agronomia, Universidade Técnica de Lisboa, Lisboa. 